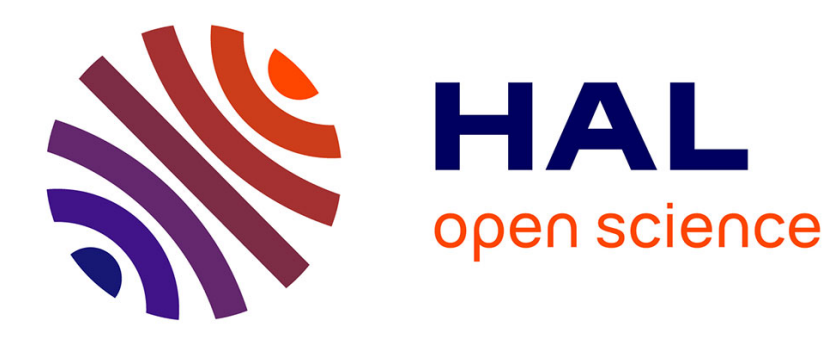

\title{
Disentangling the effect of Trust on Bank Lending
}

Christina Nicolas, Amine Tarazi

\section{To cite this version:}

Christina Nicolas, Amine Tarazi. Disentangling the effect of Trust on Bank Lending. 2019. hal02384495

\section{HAL Id: hal-02384495 \\ https: / hal-unilim.archives-ouvertes.fr/hal-02384495}

Preprint submitted on 28 Nov 2019

HAL is a multi-disciplinary open access archive for the deposit and dissemination of scientific research documents, whether they are published or not. The documents may come from teaching and research institutions in France or abroad, or from public or private research centers.
L'archive ouverte pluridisciplinaire HAL, est destinée au dépôt et à la diffusion de documents scientifiques de niveau recherche, publiés ou non, émanant des établissements d'enseignement et de recherche français ou étrangers, des laboratoires publics ou privés. 


\title{
Disentangling the effect of Trust on Bank Lending
}

\author{
Christina NICOLAS ${ }^{\text {ab* }}$ Amine TARAZI ${ }^{\text {ac }}$ \\ ${ }^{a}$ Université de Limoges, LAPE, 5 rue Félix Eboué, 87031 Limoges Cedex, France \\ ${ }^{b}$ University of Applied Sciences Western Switzerland, HEG, rue de la Tambourine 17, 1227 Carouge, \\ Switzerland \\ ${ }^{c}$ Institut Universitaire de France (IUF), 1 rue Descartes, 75231 Paris Cedex 05, France
}

This Draft: August 12, 2019

Please do not quote without the permission of the authors.

\begin{abstract}
This paper examines the effect of trust on bank lending using a sample of commercial banks in 34 countries around the world. We distinguish between two forms of trust: In-group trust, which we define as the trust in people we know, and Out-group trust, which we define as the trust in people we meet for the first time. We find that that Out-group trust significantly boosts bank lending. A closer look shows that this effect only holds in countries with relatively lower levels of institutional and judicial development. As for In-group trust, we find that it affects bank lending indirectly by favoring the development of informal lending. Overall, this paper provides novel evidence on the importance of trust and the mechanisms by which it influences bank lending around the world.
\end{abstract}

JEL classification: G21, G28, G32

Keywords: Bank Lending, Trust, Institutional Development

*Corresponding author.Email: christina.nicolas@unilim.fr , (C. Nicolas) 


\title{
Disentangling the effect of Trust on Bank Lending
}

This Draft: August 12, 2019

Please do not quote without the permission of the author.

\begin{abstract}
This paper examines the effect of trust on bank lending using a sample of commercial banks in 34 countries around the world. We distinguish between two forms of trust: In-group trust, which we define as the trust in people we know, and Out-group trust, which we define as the trust in people we meet for the first time. We find that that Out-group trust significantly boosts bank lending. A closer look shows that this effect only holds in countries with relatively lower levels of institutional and judicial development. As for In-group trust, we find that it affects bank lending indirectly by favoring the development of informal lending. Overall, this paper provides novel evidence on the importance of trust and the mechanisms by which it influences bank lending around the world.
\end{abstract}

JEL classification: G21, G28, G32

Keywords: Bank Lending, Trust, Institutional Development 


\subsection{Introduction}

Over the last two decades, trust has evolved to become a prominent concern in various fields. However, the essential role of trust as an important driver of any economic activity has been documented decades ago (Arrow, 1972) and a rich literature exists on the role of trust in financial and economic development (Bjornskov 2012; Gennaioli et al., 2015) as well as macroeconomic stability (Sangnier 2013).

Perhaps the most comprehensive definition of trust is the one which appears in Gambetta (1998): "trust is a particular level of the subjective probability with which an agent assesses that another agent or group of agents will perform a particular action, both before he can monitor such action and in a context in which it affects his own action". It follows that trust is dependent on both the propensity of trust of the individual who has to trust and the perceived trustworthiness of the trusted subject (Mayer et al., 1995).

Economic and social well-being are found to prosper in societies with high levels of trust (Arrow 1972, Fukumaya 1975). Thus, trust is widely considered as an essential lubricant to any economic activity. In that respect, there is a broad literature on the role of trust in the success of different economic phenomena. The focus of this literature has been mainly on general trust and its contribution to financial development, economic growth and prosperity (Knack and Keefer, 1997; Guiso 2004, 2008, 2010; Bjornskov 2012; Gennaioli et al., 2015). The literature provides solid evidence on the positive effect of trust on economic growth (Putnam, 1993, Shleiferand Vishny, 1997; Zak and Knack, 2001). The positive impact of trust is also documented in the study of stock market participation. Guiso et al. (2008) and El-Attar and Poschke (2011) show that individuals who trust less are less likely to invest in stocks and risky assets. Likewise, Georgarakos and Pasini (2011) show that trust in financial advisory institutions is a prominent driver of investment in the stock market. 
While the importance of trust is well recognized, surprisingly, little has been documented on the role of trust in bank lending. Arrow (1972), states that an element of trust is found in every commercial transaction. This is expected to be especially relevant when analyzing lending decisions. In effect, contracting a loan is highly dependent on the perceived repayment probability. When confronted with a loan demand, a banker faces a situation of information asymmetry involving adverse selection and moral hazard (Shapiro and Stiglitz 1984). Trust in this sense may influence the outcome of the loan contracting decision of the banker by reducing the uncertainty in both: the reliability of the borrower and the viability of the project. The literature documents an important role played by trust in reducing adverse selection and moral hazard (Nooteboomet al., 1997).

It follows that bank lending is highly dependent on trust and in several different ways. In this paper, our aim is to focus on the mechanisms by which trust drives or deters bank lending. Specifically, we focus on two sub-components of trust in others: In-group trust (also dubbed private or particularized trust) and Out-group trust (also dubbed public or generalized trust). We follow Lei and Vesely (2010) and dub In-group trust the trust an individual has in people he knows, being friends, family, relatives, or neighbors. Consequently, we refer to trust in people we do not know or people we meet for the first time as Out-group trust. By doing so, we aim to disentangle the interplay between In-group trust, Out-group trust, and each of bank lending and informal lending. We expect In-group trust to indirectly influence bank lending by boosting informal lending. Informal lending is defined as borrowing money from a friend or relative $^{1}$. Hence, by favoring informal lending in regions where In-group trust is high, bank lending is expected to develop at a lower rate as people will be less relying on banks to obtain funding. As for Out-group trust, we predict a direct positive influence on bank lending. The more the population is endowed with higher levels or generalized trust, the more confident

\footnotetext{
${ }^{1}$ Allen et al (2008) distinguish between constructive informal financing and underground informal financing. In this paper, informal financing is solely based on loans obtained from social relationships.
} 
credit officials will be in contracting loans and hence bank lending is expected to grow at a higher pace, ceteris paribus.

In the literature, we find some studies linking lending to trustworthiness. In their study, Duarte et al. (2012) use photographs of borrowers from a peer-to-peer lending website. They find that borrowers who appear more trustworthy on their photographs have higher chances of having their loans accepted. The authors conclude that trustworthiness highly matters in lending decisions. Cornett et al. (2018) study the effect of social capital on bank behavior in the U.S.. They find that higher social capital is associated with lower loan rates. Likewise, Howorth and Moro (2012) provide evidence of a negative effect of trustworthiness on interest rates charged to SMEs in Italy. Hasan et al. (2017) show that banks in U.S. counties having higher social capital levels have lower bank loan spreads.

Moro and Fink (2013) show that higher levels of trust are associated with higher lending to SMEs. The particular role of trust is more pronounced for relatively smaller firms whose profiling is less developed in terms of facts and figures. Beckman and Mare (2017) study the saving behavior of households in 10 emerging countries in Europe. Using survey data, they find that trust in financial institutions significantly influences households' saving behavior. Hence, other than facilitating loan acceptance (supply side), trust might also influence households' loan demand (demand side).

Others studies in the field point out that the effect of trust might also depend on the regulatory and institutional environments. Nguyen et al (2007) show that the role of trust in determining bank lending to SMEs in Vietnam is much more important in countries with relatively lower institutional development and judicial efficiency. Likewise, Meng and Yin (2019) find that the effect of trust on the cost of debt is much more pronounced in countries with lower regulatory and judicial efficiency. 
In a recent paper, Levine et al. (2018) use data from 34 countries to study the effect of trust on firm resiliency to banking crisis. They find that in high trust economies, firms are more resilient. They attribute this finding to the fact that bank lending is restrained during banking crisis. Consequently, higher societal trust, which facilitates informal lending, makes firms suffer less compared to similar firms in economies endowed with lower societal trust.

Despite the above literature, we still know little about how trust influences bank-lending growth around the world. We make several steps to improve our understanding of how different forms of trust affect lending. First, we use a diversified world sample of banks operating in 34 countries around the world. This provides geographic and cultural heterogeneity in our empirical analysis. Second, we take into consideration different elements of trust and disentangle their effect on lending. Our study is the first to distinguish the mechanisms by which different measures of trust influence bank lending directly and indirectly. We do so by distinguishing between two forms of trust. Third, we also focus on the role of informal lending and its interplay with bank lending and trust. Fourth, we go further in our analysis by studying how the impact of trust differs according to formal institutional development.

To conduct our empirical analysis, we use a sample of bank-level and country-level data from 34 countries around the world for the period extending from 2005 to 2015 . We make use of the data from the World Value Survey Waves 5 and 6 to construct our trust variables. We construct a lending model with the annual loan growth rate as the dependent variable to study the determinants of bank lending and the mechanism by which it is influenced by trust levels. We control for various bank level and macroeconomic factors that might influence bank lending. Our results provide evidence of a significant positive effect of Out-group trust on bank lending. A closer look shows that this effect only holds in countries with relatively low levels of institutional and judicial development. In-group trust, on the contrary, by boosting informal lending, negatively influences bank-lending growth. 
Our results provide solid evidence that as formal institutions develop, the importance of social capital, and more particularly trust in determining the outcome of a loan demand diminishes. It follows that trust is a key element, which must not be disregarded when studying lending, especially in underdeveloped economies.

The remainder of the paper is organized as follows. Section 2 is devoted to the presentation of the sample employed, the variables used as well as the econometric model and methodology. Section 3 discusses the main results and presents some robustness checks. Finally, Section 4 offers some concluding remarks. 


\subsection{Sample and Methodology}

\subsubsection{Sample}

Our sample consists of commercial banks operating in 34 countries around the world. The sample selection is based on the availability of adequate and sufficient bank-level and macrolevel data. The data we employ in this analysis comes from different sources. Bank-level variables are extracted from Bureau Van Dijk Database. Trust data is sourced from the World Value Survey waves 5 and 6. Other macroeconomic data is extracted from the World Bank database.

\subsubsection{Variables}

\subsubsection{Dependent Variable}

The main dependent variable employed is the annual growth rate of total gross loans $(G G L)$ following Gambacorta and Mistrulli (2004), Berrospide and Edge (2010), and Foos et al. (2010). Total loans include mortgage loans (residential and other mortgage loans), consumer and retail loans, corporate and commercial loans and other loans to the non-financial sector. Loan variables as well as other bank-specific variables are extracted form Bureau Van Dijk BankScope database.

\subsubsection{Independent variables}

\subsection{Trust Variables and Informal Lending}

We extract trust variables from Wave 5 and 6 of the World Value Survey. Due to high correlation of trust variables between the two waves, we use only values from Wave 6 (which is more complete) when a country is present in both. If a country is present in one of both, the only available value is used. This also allows the inclusion of a larger number of countries. 
We distinguish between two forms of trust: In-group trust ${ }^{2}$, or particularized trust, which we define as individuals' trust in people they know (INGRP_TRUST). Specifically, this variable measures the percentages of respondents who answer: "completely trust in the family, in the neighborhood, and in people you know". The other form of trust is the generalized trust or Out-group trust (OUTGRP_TRUST). This form of trust measures individuals' trust in people they meet for the first time (percentage of those who respond completely trust).

To account for the development of informal lending in a country, we add to the model the variable, informal_lending, which is extracted from the Global financial indicators of the World Bank. It measures the percentage of individuals in a country who have responded that they have previously borrowed money from a friend or relative.

\subsection{Bank Specific variables}

We use a set of bank level variables. Time-varying bank-specific variables are lagged one year in order to deal with possible endogeneity issues. TCR is the total capital adequacy ratio. This ratio as per Basel III rules is the ratio of the sum of Tier 1 and Tier 2 capital (hybrid capital, subordinated debt, reserves for loan losses, and valuation reserves) to total riskweighted assets and off-balance sheet items. The reason behind using regulatory capital ratios and not simple leverage non-weighted ratios is mainly because risk-weighted capital ratios better reflect a bank's solvency (Gambacorta and Marquez-Ibanez 2004). While some papers document a significant negative effect of capital ratios on lending (Bernanke and Lown (1991), Berger and Udell (1994), Peek and Rosengren(2000), Gambacorta and Marques Ibanez (2011)), others find a positive effect (Furlong (1992), Holmström and Tirole (1997) Berrospide and Edge (2010), Brei et al. (2013), Bridges et al. (2014) and Košak et al. (2015). On the one hand, an increase in capital ratios increases a bank's solvency. In other words, the

\footnotetext{
${ }^{2}$ We follow Lei and Vesely (2010) in the terminology: In-group and Out-group trust.
} 
higher the capital ratios, the more the bank will be willing to extend credit since capital serves as a cushion against unforeseen adverse shocks. Thus, the positive relationship between capital ratios and bank lending. On the other hand, since raising capital is expensive, many banks might increase their capital ratios by cutting down on their lending or shifting some of their loans from high credit risk (e.g.: commercial loans) to risk-free treasuries. In this perspective, a decrease in lending is observed when studying only commercial bank loans. We control for banks' risk appetite using the ratio of non-performing loans to total loans (NPLGL) as in Fiordelisi et al. 2011 and Distinguin et al. 2013. We expect risk to negatively influence loan growth. Banks' lending desire is expected to decrease when facing a higher credit risk due to a worsened loan quality ((Berrospide and Edge, 2010 and Cucinelli, 2015). We proxy for liquidity using the ratio of loans to total assets (NLTA) as in Valverde and Fernandez (2007). This ratio indicates what percentage of the bank's assets are tied up in loans. The higher the ratio, the less liquid the bank will be. Less liquid banks are expected to exhibit lower loan growth rates as liquidity is considered as a major constraint to credit supply. Finally, since large banks might behave differently compared to smaller banks, we control for bank size using the logarithm of total assets held by banks (log_TA).

\subsection{Macroeconomic variables and other independent variables}

Controlling for country-level macroeconomic factors is essential when studying bank loan growth. Many studies have shown that macroeconomic variables explain credit growth to a very large extent (Berrospide and Herrerias 2015, Brei et al 2013, Gambacorta 2005). Macroeconomic data is sourced from the World Bank databases.

To control for the macroeconomic environment, two measures accounting for the nominal GDP growth rate and the prevailing interest rate are included in the model. The GDP growth (GDP_Gr) is the annual growth rate of the domestic product in a given economy. 
During an economic boom, investment rises and demand for credit is expected to increase as well (Talavera et al., 2012, Chen et al., 2010). Banks in upturns are encouraged to lend more as the demand for credit also increases. GDP growth is expected to positively influence loan growth.

To control for the interest rate and inflation in a given country and consequently the effect of the central bank's monetary policy on lending, we use the real interest rate (RIR) from the World Bank database which is the annual nominal lending rate after accounting for the annual inflation rate. Due to high correlation between inflation and the nominal interest rate including these two variables would generate collinearity issues.

Moreover, bank lending might be dependent on the relative development of capital markets. Consequently, we proxy for stock market development by using the stock market capitalization to GDP ratio. Due to high correlation of this variable with other variables, we only include in our model a dummy variable (MK_GDPdum) which is equal to one if the country exhibits stock market development to GDP higher than the sample median and zero otherwise. This dummy variable thus controls for whether banks in countries with highly developed stock markets behave differently compared to countries where stock markets are less developed. MK_GDPdum is expected to negatively influence bank lending as reliance on bank lending is expected to be lower in countries with more developed capital markets.

Another element that might influence bank lending is bank concentration. For this purpose, we add to our model the variable BANK_CONC which is the ratio of the total assets of the five largest banks to total country banking assets expressed in percentage. Higher concentration implies lower competitiveness which might push banks to increase their lending rates which in turn may lead to lower demand for bank credit (Beck et al. 2004). Thus, bank concentration is expected to have a negative effect on lending. 
Finally, we add to the model a dummy variable accounting for mergers and acquisitions. M\&As are usually associated with an external peak in credit growth. We aim to control for any spurious loan growth that might be simply reflecting a larger loan portfolio originating from an acquisition. As in Roulet (2018), we use a dummy variable to account for M\&As (dum_GTA) and deal with the important noise that such effects might bring to the regression. This variable takes the value of 1 for an asset growth higher than $35 \%$ and zero otherwise.

\subsubsection{Empirical Model}

The econometric model we wish to estimate is the following:

$\mathrm{GGL}_{\mathrm{ijt}}=\alpha_{0}+\beta_{1}$ TRUST $_{\mathrm{jt}}+\beta_{2}$ informal_lending $_{\mathrm{jt}}+\beta_{3}$ Bank $_{\mathrm{ijt}}+\beta_{4}$ Macro $_{\mathrm{jt}}+$ Date $_{\mathrm{t}}+\mathrm{t}$

Where $G G L_{i j t}$ is the growth rate of bank loans of bank i in country $\mathrm{j}$ at year

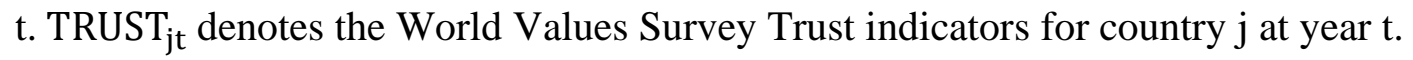

Informal_lending is a measure of the importance of informal credit in country $\mathrm{j}$ at year $\mathrm{t}$. We include a set of bank characteristics Bank $k_{i j t}$ which includes measures of capital ratio, size, risk, and liquidity. Macro $_{j t}$ is a vector of macroeconomic variables controlling for GDP growth, the real interest rate, bank concentration, and stock market capitalization. This vector also includes a dummy variable accounting for a sharp increase in total assets capturing mergers and acquisitions.

We also study how informal lending can affect the impact of trust on bank loan growth. For this purpose, we add to Model 1 an interaction term between Trust and Informal lending as follows: 
$\mathrm{GGL}_{\mathrm{ijt}}=\alpha_{0}+\beta_{1}$ TRUST $_{\mathrm{jt}}+\beta_{2}$ informal_lending $_{\mathrm{jt}}+\beta_{3}$ TRUST $_{\mathrm{jt}} *$ informal_lending $+_{-}$

$\beta_{4}$ Bank $_{i j t}+\beta_{5}$ Macro $_{j t}+$ Date $_{t}+\mathfrak{t}$

\subsubsection{Estimation Methodology}

In our econometric approach, we employ a static panel regression model. This is in accordance with previous studies (see e.g. Kanagaretnam et al., 2011, 2004) utilizing static specifications. We use the Wooldridge test (Wooldridge 2002) to validate that for the case of our data, using a static model is appropriate. The null hypothesis under which there is no firstorder autocorrelation cannot be rejected. Hence, there is no serial correlation in the idiosyncratic error term, which confirms the appropriateness of using the static regression model on our data. We believe that we capture a fair amount of heterogeneity across banks, countries, and time across the panel by using a set of bank-level and country-level variables as well as year dummies respectively, thus minimizing any bias in the parameters. In addition, we correct for heteroskedasticity and serial dependence in our data by using robust standard errors clustered at the bank level (Petersen, 2009). Moreover, we use the growth rates for the dependent variable, bank lending, and not level values. We also use the first lag of all bankspecific variables in order to deal with possible endogeneity issues. Considering the panel nature of our sample as well as the absence of the time dimension in the main independent variables of interest, we use the random effects estimator to estimate our model, which is validated by using the Breusch and Pagan Lagrange-multiplier test ${ }^{3}$.

\footnotetext{
${ }^{3}$ We reject the null (under which the variance of the unobserved fixed effects is null) and thus conclude that the random effects estimator is more appropriate; significant differences across countries exist which makes the use of Random Effects more appropriate.
} 


\subsection{Empirical Results}

\subsubsection{Descriptive statistics}

Table (1) presents the descriptive statistics of the full sample. Table (2) displays variable means by country. The sample average of loan growth is at $13.8 \%$ with the lowest rate observed in Japan (3.5\%). In-group trust varies between a low of $29.34 \%$ in Japan to a high of $67.6 \%$ in Egypt. France is the country in our sample which records the highest values of both trust indicators among all countries (61.2\% for In-group trust and 20.7\% for Out-group trust).

Table 3.1. Descriptive statistics

\begin{tabular}{lrlrrr} 
Variable & Obs & Mean & Std. Dev. & \multicolumn{1}{l}{ Min } & \multicolumn{1}{c}{ Max } \\
GGL & 5087 & 13.64718 & 21.0932 & -43.71 & 214.05 \\
Informal_lending & 5087 & 18.82653 & 13.58592 & 3.281787 & 71.19629 \\
INGRP_TRUST & 5087 & 39.24172 & 8.40347 & 29.36667 & 67.63333 \\
OUTGRP_TRUST & 5087 & 2.788444 & 3.328641 & 0.333333 & 20.73333 \\
TCR & 4857 & 15.25566 & 6.453393 & 8.32 & 62.36 \\
log_TA & 5066 & 15.76564 & 1.609614 & 10.34851 & 18.59122 \\
NPLGL & 4874 & 4.306744 & 4.532009 & 0 & 32.9 \\
NLTA & 5087 & 58.43138 & 17.05748 & 0.424 & 98.935 \\
GDPgr & 5087 & 3.610961 & 3.884124 & -7.79728 & 15.24038 \\
MK_GDP & 5087 & 69.26354 & 46.0711 & 0.873386 & 299.5737 \\
RIR & 5087 & 3.377539 & 3.215078 & -9.04454 & 22.32388 \\
BANK_CONC & 5087 & 63.89597 & 13.58453 & 39.37 & 99.46 \\
dum_GTA & 5087 & 0.087675 & 0.282849 & 0 & 1
\end{tabular}

This tables displays the descriptive statistics for the whole sample for the period 2005-2015. GGL, the annual loan growth rate. Informal_lending is the percentage of individuals in a country who have responded that they have taken an informal credit. INGRP_TRUST is percentage of individuals who have responded that they completely trust people they know. OUTGRP_TRUST is the percentage of individuals who have responded that they completely trust people they meet for the first time. TCR is the total regulatory capital ratio. $\log$ TA is the log of total banking assets. NPLGL is the first lag of the ratio of non-performing loans to gross loans. NLTA is the ratio of net loans to total assets. GDPgr is the growth rate of the Gross domestic product. MK_GDP is a dummy for stock market development. RIR is the real interest rate. BANK_CONC is a measure of bank concentration. Dum_GTA if a dummy controlling for spurious asset growth. All the ratios are expressed in percentages. Size is the natural logarithm of total assets. All the ratios are expressed in percentages. Size is the natural logarithm of total assets. 
Table 3.2. Main Descriptive statistics by country

\begin{tabular}{|c|c|c|c|}
\hline Country & GGL & INGRP_TRUST & OUTGRP_TRUST \\
\hline ARGENTINA & 25.29952 & 49.25 & 7.933333 \\
\hline ARMENIA & 38.75649 & 43.53333 & 1 \\
\hline BULGARIA & 21.54609 & 45.16667 & 3.3 \\
\hline CANADA & 10.87697 & 50.1 & 3.366667 \\
\hline CHILE & 16.92823 & 38.48333 & 3.516667 \\
\hline CHINA & 20.70861 & 41.6 & 1.066667 \\
\hline COLOMBIA & 22.37707 & 34.2 & 2.266667 \\
\hline CYPRUS & 16.66897 & 42.6 & 2 \\
\hline EGYPT & 12.28709 & 67.63333 & 3.466667 \\
\hline FRANCE & 4.625455 & 61.26667 & 20.73333 \\
\hline GERMANY & 4.531266 & 37.51667 & 2.2 \\
\hline HUNGARY & 6.167778 & 48 & 10.03333 \\
\hline INDIA & 20.23771 & 50.66666 & 8.833333 \\
\hline INDONESIA & 24.52822 & 38.26667 & 1.466667 \\
\hline ITALY & 10.53803 & 34.63333 & 0.7333333 \\
\hline JAPAN & 3.507263 & 29.36667 & 0.3333333 \\
\hline JORDAN & 8.391 & 54.03333 & 3.85 \\
\hline LEBANON & 20.64253 & 36 & 8.833334 \\
\hline MALAYSIA & 14.54806 & 38.38333 & 1.433333 \\
\hline NETHERLANDS & 15.24273 & 33.9 & 1.4 \\
\hline PERU & 23.26227 & 31.13333 & 1.133333 \\
\hline PHILIPPINES & 17.32006 & 41.13334 & 3.4 \\
\hline POLAND & 13.0275 & 29.5 & 1.183333 \\
\hline ROMANIA & 20.10396 & 31.46667 & 1.633333 \\
\hline SINGAPORE & 19.15304 & 43.5 & 4.633333 \\
\hline SLOVENIA & 7.158191 & 39.85 & 2.333333 \\
\hline SOUTH AFRICA & 14.10387 & 41.56667 & 9.7 \\
\hline SPAIN & 7.833373 & 51.7 & 4.916667 \\
\hline SWITZERLAND & 6.362 & 44.76667 & 3.766667 \\
\hline THAILAND & 12.21317 & 42.9 & 3.883333 \\
\hline \multicolumn{4}{|l|}{ UNITED } \\
\hline KINGDOM & 16.18151 & 52.26667 & 6.766667 \\
\hline VIETNAM & 23.79606 & 42.9 & 0.9 \\
\hline ZAMBIA & 26.42286 & 30.76667 & 4.333333 \\
\hline Total & 13.76515 & 39.26101 & 2.765314 \\
\hline
\end{tabular}

This tables displays the mean levels by country for the period 2005-2015. GGL, the annual loan growth rate. Informal_lending is the percentage of individuals in a country who have responded that they have taken an informal credit. INGRP_TRUST is percentage of individuals who have responded that they completely trust people they know. OUTGRP_TRUST is the percentage of individuals who have responded that they completely trust people they meet for the first time. 
Table (3) displays the correlation matrix. No major correlation exists between independent variables, which implies that our regression does not suffer from possible multicollinearity issues. We also perform the variance inflation factor (VIF) to further confirm this. We obtain a mean VIF equal to 1.3 (considerably lower than 10, the critical value) which further alleviates multicollinearity issues. 
Table 3.3. Correlation matrix

\begin{tabular}{|c|c|c|c|c|c|c|c|c|c|c|c|c|}
\hline & GGL & TCR & $\begin{array}{l}\text { INGRP } \\
\text { _TRUST }\end{array}$ & $\begin{array}{l}\text { OUTGR } \\
\text { P_TRUST }\end{array}$ & log_TA & NPLGL & NLTA & GDPgr & MK_GDP & RIR & $\begin{array}{l}\text { BANK_ } \\
\text { CONC }\end{array}$ & $\begin{array}{l}\text { Dum } \\
\text { _GTA }\end{array}$ \\
\hline TCR & 0.0791 & 1 & & & & & & & & & & \\
\hline INGRP_TRUST & 0.1328 & 0.1697 & 1 & & & & & & & & & \\
\hline OUTGRP_TRUST & 0.0639 & 0.0684 & 0.6556 & 1 & & & & & & & & \\
\hline log_TA & -0.1701 & -0.4181 & -0.1718 & -0.0686 & 1 & & & & & & & \\
\hline NLTA & -0.0831 & -0.2339 & -0.1647 & -0.0797 & 0.0143 & -0.0089 & 1 & & & & & \\
\hline GDPgr & 0.3073 & 0.0538 & 0.316 & 0.1703 & -0.0845 & -0.2255 & -0.2398 & 1 & & & & \\
\hline MK_GDPdum & 0.0178 & 0.1013 & 0.1786 & 0.1806 & -0.1239 & -0.1069 & 0.0189 & 0.102 & 1 & & & \\
\hline RIR & 0.0128 & 0.0571 & -0.0131 & 0.134 & -0.0957 & 0.1244 & 0.0622 & -0.0971 & -0.0854 & 1 & & \\
\hline
\end{tabular}




\subsubsection{Regression results}

The results of the main regression are presented in Table (4). The results show a significant positive link between Out-group trust and bank loan growth. Bank managers in countries where generalized trust is higher might be willing to provide a higher number of bank loans because they suspect that agents in such countries are more likely to honor their fiduciary obligations, and to follow social norms of behavior which makes them more trustworthy. Hence, the positive effect of Out-group trust on bank lending. Moreover, higher societal trust reduces the cost of obtaining information and increases the quality of available information, which gives bank managers more visibility of their debtors. Hence, by enhancing loan repayment probability and reducing selection bias, Out-group trust boosts bank lending. As for In-group trust, we find that it is positively associated with bank lending when informal lending is not important. Still, this positive association weakens when informal lending is more important. This is portrayed on the negative significant sign on the interaction term between In-group trust and informal lending. This finding is consistent with our hypothesis that In-group trust influences bank lending indirectly by boosting informal lending. Higher Ingroup trust boosts informal lending since people are willing to provide more loans to their family and people they know when the loan repayment probability is higher (due to higher trust levels in their family and people they know). Thus, In-group trust influences bank lending indirectly by favoring informal lending.

Concerning bank-level variables, we find that larger and riskier banks exhibit lower loan growth while more liquid and more capitalized banks exhibit higher loan growth, consistent with existing literature. Bank concentration, on the contrary doesn't seem to impact bank lending. Among macroeconomic variables, we find a positive significant link between GDP growth and bank lending, which is expected since bank lending flourishes during upturns. The coefficient of the proxy of stock market development, on the contrary, is 
significantly negative consistent with the fact that countries with less developed stock markets are more reliant on bank lending.

Table 3.4. Main regression results

\begin{tabular}{|c|c|c|c|c|}
\hline & (1) & (2) & (3) & (4) \\
\hline & GGL & GGL & GGL & GGL \\
\hline informal_lending & $\begin{array}{l}-0.0146 \\
(-0.43)\end{array}$ & $\begin{array}{l}-0.0165 \\
(-0.49)\end{array}$ & $\begin{array}{l}0.748 * * * \\
(3.44)\end{array}$ & $\begin{array}{l}-0.0121 \\
(-0.23)\end{array}$ \\
\hline INGRP_TRUST & $\begin{array}{l}0.00626 \\
(0.14)\end{array}$ & & $\begin{array}{l}0.304^{* * *} \\
(3.22)\end{array}$ & \\
\hline OUTGRP_TRUST & & $\begin{array}{l}0.261^{* *} \\
(2.41)\end{array}$ & & $\begin{array}{l}0.278^{*} \\
(1.68)\end{array}$ \\
\hline INGRP_TRUST*informal_lending & & & $\begin{array}{l}-0.0191^{* * *} \\
(-3.58)\end{array}$ & \\
\hline OUTGRP_TRUST*informal_lending & & & & $\begin{array}{l}-0.00103 \\
(-0.14)\end{array}$ \\
\hline L.TCR & $\begin{array}{l}0.226^{* *} \\
(2.48)\end{array}$ & $\begin{array}{l}0.224^{* *} \\
(2.46)\end{array}$ & $\begin{array}{l}0.218^{* *} \\
(2.38)\end{array}$ & $\begin{array}{l}0.224^{* *} \\
(2.44)\end{array}$ \\
\hline L.log_TA & $\begin{array}{l}-1.448 * * * \\
(-5.21)\end{array}$ & $\begin{array}{l}-1.451 * * * \\
(-5.24)\end{array}$ & $\begin{array}{l}-1.338^{* * *} \\
(-4.80)\end{array}$ & $\begin{array}{l}-1.448^{* * *} \\
(-5.22)\end{array}$ \\
\hline L.NPLGL & $\begin{array}{l}-0.624 * * * \\
(-6.41)\end{array}$ & $\begin{array}{l}-0.637^{* * *} \\
(-6.53)\end{array}$ & $\begin{array}{l}-0.619 * * * \\
(-6.35)\end{array}$ & $\begin{array}{l}-0.637^{* * *} \\
(-6.53)\end{array}$ \\
\hline L.NLTA & $\begin{array}{l}-0.262^{* * *} \\
(-8.18)\end{array}$ & $\begin{array}{l}-0.259 * * * \\
(-8.12)\end{array}$ & $\begin{array}{l}-0.262^{* * *} \\
(-8.19)\end{array}$ & $\begin{array}{l}-0.259 * * * \\
(-8.11)\end{array}$ \\
\hline GDPgr & $\begin{array}{l}0.774^{* * *} \\
(7.04)\end{array}$ & $\begin{array}{l}0.758^{* * *} \\
(6.98)\end{array}$ & $\begin{array}{l}0.746^{* * *} \\
(6.78)\end{array}$ & $\begin{array}{l}0.755^{* * *} \\
(6.75)\end{array}$ \\
\hline MK_GDPdum & $\begin{array}{l}-2.718^{* *} \\
(-1.96)\end{array}$ & $\begin{array}{l}-2.964^{* *} \\
(-2.11)\end{array}$ & $\begin{array}{l}-2.591^{*} \\
(-1.88)\end{array}$ & $\begin{array}{l}-2.950 * * \\
(-2.07)\end{array}$ \\
\hline RIR & $\begin{array}{l}-0.00913 \\
(-0.10)\end{array}$ & $\begin{array}{l}-0.0248 \\
(-0.26)\end{array}$ & $\begin{array}{l}-0.0381 \\
(-0.40)\end{array}$ & $\begin{array}{l}-0.0257 \\
(-0.27)\end{array}$ \\
\hline BANK_CONC & $\begin{array}{l}-0.0369 \\
(-1.06)\end{array}$ & $\begin{array}{l}-0.0358 \\
(-1.04)\end{array}$ & $\begin{array}{l}-0.0595 \\
(-1.64)\end{array}$ & $\begin{array}{l}-0.0358 \\
(-1.04)\end{array}$ \\
\hline dum_GTA & $\begin{array}{l}29.32 * * * \\
(15.47)\end{array}$ & $\begin{array}{l}29.41^{* * *} \\
(15.52)\end{array}$ & $\begin{array}{l}29.27^{* * *} \\
(15.41)\end{array}$ & $\begin{array}{l}29.41^{* * *} \\
(15.49)\end{array}$ \\
\hline Constant & $\begin{array}{l}48.76 * * * \\
(7.25)\end{array}$ & $\begin{array}{l}48.29 * * * \\
(7.47)\end{array}$ & $\begin{array}{l}37.40 * * * \\
(5.25)\end{array}$ & $\begin{array}{l}48.19 * * * \\
(7.50)\end{array}$ \\
\hline Nbr. of obs. & 5087 & 5087 & 5087 & 5087 \\
\hline $\mathrm{Nbr}$. of groups & 1075 & 1075 & 1075 & 1075 \\
\hline \multirow[t]{2}{*}{$\mathrm{r} 2$} & 0.287 & 0.287 & 0.288 & 0.287 \\
\hline & & 0.28509 & & 0.2767 \\
\hline
\end{tabular}


Wald test

Walt test $P$-value

0.001

0.083

This tables displays the main regression results using OLS with the random effects estimator. GGL, the annual loan growth rate is the dependent variable in all regressions. Informal_lending is the percentage of individuals in a country who have responded that they have taken an informal credit. INGRP_TRUST is percentage of individuals who have responded that they completely trust people they know. OUTGRP_TRUST is the percentage of individuals who have responded that they completely trust people they meet for the first time. TCR is the total regulatory capital ratio. L. $\log _{-}$TA is the first lag of the log of total banking assets. NPLGL is the first lag of the ratio of nonperforming loans to gross loans. L.NLTA is the first lag of the ratio of net loans to total assets. GDPgr is the growth rate of the Gross domestic product. MK_GDP is a dummy for stock market development. RIR is the real interest rate. BANK_CONC is a measure of bank concentration. Dum_GTA if a dummy controlling for spurious asset growth. All the ratios are expressed in percentages. Size is the natural logarithm of total assets. Reported beneath each coefficient estimate is the t-statistic adjusted for clustering at the bank level. *, ** and *** indicate statistical significance at the $10 \%, 5 \%$ and $1 \%$ levels, respectively.

\subsubsection{Further Investigations and Robustness Checks}

First, we conduct marginal analysis to shed light on the actual impact of trust on formal bank lending at different values of informal lending. We display the results in Table (5). Results show that the negative link between In-Group trust and bank lending becomes more pronounced as informal lending increases. For the highest percentile of informal lending, Ingroup trust has the strongest negative link with bank lending as shown by the value of the regression coefficient which continuously declines across the different percentiles from -0.173 to $-0.651,-1.127$ and -1.413 .

Second, in their paper, Nguyen et al (2006) show that the role of trust in determining bank lending is much more important in countries with relatively lower institutional development and judicial efficiency. We thus study whether the relationship between trust and loan growth is conditional on the level of formal institutional development. This can be excepted since bank managers in countries with lower institutional development might rely more on trust when deciding to provide a loan. Hence, Out-group trust is expected to boost lending more in countries with lower institutional development compared to countries who already have effective institutions. To test this empirically, we split our sample into two sub samples: above and below the median value of an index measuring institutional development 
following Alraheb et al. (2019) ${ }^{4}$. Results are presented in Table 6. Columns (1) and (2) show results for the sample of banks operating in countries with high institutional development while columns (3) and (4) display results for banks in countries with relatively lower levels of institutional development. Findings show that Out-group trust is highly significant in explaining bank loan growth (at the $1 \%$ confidence level) but only for banks in countries with low institutional development. We do not find any significance for the sub sample of banks operating in countries with high institutional development. This confirms the findings of Nguyen et al. (2006) whereby the importance of the effect of trust on bank lending is much more pronounced in countries where institutions are relatively less developed. It follows that that reliance on trust when making lending decisions in economies where institutions (which legitimate markets) are deficient is usually higher.

Table 3.5. Trust and Bank lending at different levels of informal lending

$\begin{array}{lcc} & & \\ \text { 25thpercentile } & \text { INGRP_TRUST } & \text { OUTGRP_TRUST } \\ & -0.173^{* *} & 0.252^{* *} \\ \text { 50thpercentile } & -0.067 & -0.121 \\ & -0.651^{* * *} & 0.226 \\ \text { 75thpercentile } & -0.189 & -0.254 \\ & -1.127^{* * *} & 0.201 \\ \text { 90thpercentile } & -0.32 & -0.422 \\ & -1.414^{* * *} & 0.185 \\ & -0.4 & -0.525\end{array}$

INGRP_TRUST is the trust in people we know. OUTGRP_TRUST is the trust in people we meet for the first time. Both measures are the percentage of the population who respond "completely trust". Standard errors are reported in parentheses below the coefficient estimates. $*$ is the statistical significance at the $10 \%$ level, $* *$ is the statistical significance at the $5 \%$ level, and $* * *$ is the statistical significance at the $1 \%$ level.

\footnotetext{
${ }^{4}$ The index is based on principal component analysis of different measures of formal institutional indicators. It is the the first principle factor of the following indicators: political stability, corruption, regulatory quality, voice and accountability, creditors' rights, and economic freedom. For further insights on this indicator please see Al Raheb et al (2019).
} 
Table 6. Trust and Bank Lending: The effect of formal institutional development

\begin{tabular}{|c|c|c|c|c|}
\hline & & $h$ inst & & inst \\
\hline & $\mathrm{GGL}$ & GGL & GGL & GGL \\
\hline informal_lending & -0.255 & -0.256 & 0.0197 & 0.0119 \\
\hline & $(-1.36)$ & $(-1.37)$ & $(0.41)$ & $(0.25)$ \\
\hline INGRP_TRUST & -0.0114 & & -0.105 & \\
\hline & $(-0.11)$ & & $(-1.55)$ & \\
\hline OUTGRP_TRUST & & -0.0823 & & $0.519 * * *$ \\
\hline & & $(-0.45)$ & & $(2.89)$ \\
\hline L.TCR & 0.0305 & 0.0311 & $0.332 * * *$ & $0.330 * * *$ \\
\hline & (0.17) & (0.17) & (2.74) & (2.76) \\
\hline L.log_TA & $-1.552 * * *$ & $-1.542 * * *$ & $-0.884^{* *}$ & $-0.918^{* *}$ \\
\hline & $(-3.35)$ & $(-3.33)$ & $(-2.23)$ & $(-2.35)$ \\
\hline L.NPLGL & $-0.417 * *$ & $-0.414 * *$ & $-0.500 * * *$ & $-0.543 * * *$ \\
\hline & $(-2.44)$ & $(-2.42)$ & $(-3.08)$ & $(-3.31)$ \\
\hline L.NLTA & $-0.265 * * *$ & $-0.266 * * *$ & $-0.251 * * *$ & $-0.233 * * *$ \\
\hline & $(-4.44)$ & $(-4.42)$ & $(-5.57)$ & $(-5.32)$ \\
\hline GDPgr & $1.114^{* * *}$ & $1.117^{* * *}$ & $0.556 * * *$ & $0.520 * * *$ \\
\hline & $(4.80)$ & $(4.81)$ & $(3.20)$ & (2.99) \\
\hline MK_GDPdum & -1.914 & -1.891 & $-6.202 * *$ & $-8.422 * * *$ \\
\hline & $(-0.93)$ & $(-0.92)$ & $(-2.46)$ & $(-3.06)$ \\
\hline RIR & 0.208 & 0.216 & 0.00555 & 0.0107 \\
\hline & $(0.85)$ & $(0.88)$ & $(0.04)$ & $(0.07)$ \\
\hline BANK_CONC & 0.0863 & 0.0901 & $-0.0930 *$ & -0.0265 \\
\hline & (1.09) & $(1.28)$ & $(-1.79)$ & $(-0.46)$ \\
\hline dum_GTA & $37.53 * * *$ & $37.53 * * *$ & $27.43^{* * *}$ & $27.65^{* * *}$ \\
\hline & $(7.30)$ & $(7.31)$ & $(13.22)$ & $(13.40)$ \\
\hline Constant & 0 & 0 & $46.51 * * *$ & $36.67 * * *$ \\
\hline & (.) & (.) & (4.28) & (3.90) \\
\hline Nbr. of obs. & 1979 & 1979 & 2501 & 2501 \\
\hline Nbr. of groups & 444 & 444 & 647 & 647 \\
\hline r2 & 0.279 & 0.280 & 0.317 & 0.313 \\
\hline
\end{tabular}

This tables displays the regression results by institutional development using OLS with the random effects estimator. GGL, the annual loan growth rate is the dependent variable in all regressions. Informal_lending is the percentage of individuals in a country who have responded that they have taken an informal credit. INGRP_TRUST is percentage of individuals who have responded that they completely trust people they know. OUTGRP_TRUST is the percentage of individuals who have responded that they completely trust people they meet for the first time. TCR is the total regulatory capital ratio. L.log_TA is the first lag of the log of total banking assets. NPLGL is the first lag of the ratio of non-performing loans to gross loans. L.NLTA is the first lag of the ratio of net loans to total assets. GDPgr is the growth rate of the Gross domestic product. MK_GDP is a dummy for stock market development. RIR is the real interest rate. BANK_CONC is a measure of bank concentration. Dum_GTA if a dummy controlling for spurious asset growth. All the ratios are expressed in percentages. Size is the natural logarithm of total assets. Reported beneath each coefficient estimate is the t-statistic adjusted for clustering at the bank level. *, ** and *** indicate statistical significance at the 10\%, 5\% and $1 \%$ levels, respectively. 


\subsection{Conclusion}

We investigate the relationship between trust and bank lending using a sample of commercial banks in 34 countries around the world for the period extending from 2005 to 2015 . Specifically, we disentangle the link between trust and bank lending by making use of its two sub-components in our analysis: In-group trust and Out-group trust. Our findings offer some interesting insights on how trust is associated with bank lending. Precisely, we find evidence of a significant positive link between Out-group trust and bank lending. A closer look shows that this effect only holds in countries with relatively low levels of institutional and judicial development. On the contrary, In-group trust is negatively associated with bank-lending growth. This effect is even more pronounced for higher levels of development of informal lending. Our results also show that as formal institutions develop, the importance of the link between trust and formal bank lending diminishes. It follows that trust seems like a key element, which must not be disregarded when studying lending, especially in countries where institutions remain underdeveloped.

Our work constitutes a first approach towards a better understanding of the exact role played by trust in bank lending development and may also provide a prelude for further research in this field. 


\section{References}

Allen, F., Qian, M., Xie, J., 2018. Understanding Informal Financing. Journal of Financial Intermediation. In Press

Alraheb, T., Nicolas, C., Tarazi, A., 2019. Institutional Environment and Bank Capital Ratios. Journal of Financial Stability 43, 1-24

Arrow, K., Gifts and Exchanges. Philosophy and Public Affairs, 1(4), 343-362

Beck, T., Demirgüç-Kunt, A., Levine, R., 2004. Finance, Inequality and Poverty: CrossCountry Evidence. Policy Research Working Paper 3338. World Bank, Washington, DC.

Beckmen, E., Mare D.S., 2017. Formal and informal household savings: how does trust in financial institutions influence the choice of saving instruments? MRPA Paper no 81141.

Berger, A., Udell, G., 1994. Do risk-based capital allocate bank credit and cause a "credit crunch" in the United States? Journal of Money, Credit, and Banking 26(3), 585-628

Berrospide, J. M., and R. M. Edge., 2010. The Effects of Bank Capital on Lending: What Do We Know, and What Does it Mean? International Journal of Central Banking 6 (4), 5-54.

Berrospide, J.M., Edge, R.M., 2010. The effects of bank capital on lending: What do we know, and what does it mean? International Journal of Central Banking 6(4), 5-54

Bjornskov, C., 2012. How does social trust affect economic growth? Southern Economic Journal 78(4), 1346-1368

Brei, M., Gambacorta, L., and von Peter, G., 2013. Rescue packages and bank lending. Journal of Banking and Finance, 37.

Bridges, J., 2014. The impact of capital requirements on bank lending. Bank of England Working Paper No. 486.Carlin B.I., Dorobantu F., Viswanthan S., 2009. Public Trust, the Law, and Financial Investment. Journal of Financial Economics 92(3), 321-341

Chen, X., Wang, X., Wu, D.D., 2010. Credit risk measurement and early warning of SMEs: An empirical study of listed SMEs in China. Decision Support Systems 49(3):301-310 Cornett, M., Minnick, K., Schorno, P., Tehranian, H., 2018. Bank Behavior and Social Capital. FMA Working Paper

Cucinelli, D., 2015. The Impact of Non-performing Loans on Bank Lending Behavior: Evidence from the Italian Banking Sector. Eurasian Journal of Business and Economics 8(16), $59-71$

Distinguin, I., Roulet, C., Tarazi, A., 2013. Bank Regulatory Capital and Liquidity: Evidence from U.S. and European Publicly Traded Banks. Journal of Banking and Finance 37(9)

Duarte, J., Siegel, S., Young, L., et al 2012. Trust and Credit: The Role of Appearance in Peer-to-peer Lending. Review of Financial Studies 25(8), 2455-2484 
El-Attar, M., Poschke, M., 2011. Trust and the choice between housing and financial assets: Evidence from Spanish households. Review of Finance 15(4), 727-756

Fiordelisi, F., Marquez-Ibanez, D., Molyneux, P., 2011. Efficiency and risk in European banking. Journal of Banking and Finance 35(5), 1315-1326

Fukuyama, F., (1995). "Trust: The social virtues and the creation of prosperity". New York: Free Press.

Foos, D., Norden, L., Weber, M., 2010. Loan growth and riskiness of banks. Journal of Banking and Finance 34(12), 2929-2940

Furlong, F., 1992. Capital regulation and bank lending. Economic Review 3, 23-33

Gambacorta, L., 2005. Inside the lending channel. European Economic Review 49(7), 1737 1759

Gambacorta, L., Marques-Ibanez, D., Spaventa, L., Haliassos, M., 2011. The bank lending channel: lessons from the crisis. Economic Policy 135, 137-182

Gambacorta L., Mistrulli, P.E., 2004. Does bank capital affect lending behavior? Journal of Financial Intermediation 13(4), 436-457

Gennnaioli, N., Shleifer, A., Vishny, R., 2015. Money doctors. The Journal of Finance 70(1), 91-114

Georgarakos, D., \& Pasini, G., 2011. Trust, sociability, and stock market participation. Review of Finance 15, 693-725.

Guiso, L., Sapienza, P., Zingales, L., 2004. The role of social capital in financial development. American Economic Review 94, 526-56.

Guiso, L., Sapienza, P., Zingales, L., 2008. Trusting the Stock Market. The Journal of Finance 63(6), 2557-2600

Gambetta, Diego (1998). "Can we trust trust?" in Trust: Making and Breaking Cooperative Relations, D. Gambetta (ed), Basil Blackwell, Cambridge: MA. chapter 13, 213-237.

Hasan, I., Hoi, C.K., Wu, Q., Zhang, H., 2017. Social Capital and Debt Contracting: Evidence from Bank Loans and Public Bonds. Journal of Financial and Quantitative Analysis 52(3), 1017-1047

Holmstrom, B., Tirole, J., 1997. Financial intermediation, loanable funds, and the real sector. Quarterly Journal of Economics 112(3), 663-691

Howowrth, C., Moro, A., 2012. Trustworthiness and interest rates: an empirical study of Italian SMEs. Small Bus Economics 39, 161-177

Kanagaretnam, K., Lobo, G.J., Yang, D., 2004. Join tests of signaling and income smoothing through bank loan provisions. Contemporary Accounting Research 21(4), 843-884. 
Kanagaretnam, K., Lim, C., Lobo, G., 2014. Influence of National Culture on Accounting Conservatism and Risk-Taking in the Banking Industry. The Accounting Review 89 (3), 1115-1149.

Knack, S., Keefer, P., 1997. Does social capital have an economic payoff? A cross-country investigation. Quarterly Journal of Economics 112 (4), 1251-1288.

Knell, M., Stix, H., 2015. Trust in Banks during Normal and Crisis Times-Evidence from Survey Data. Economica 82, 995-1020.

Kosak, M., Li, S., Loncarski, I., Marinc, M., 2015. International Review of Financial Analysis $37,168-183$

Lei, V., and Vesley, F., 2010. In-Group versus Out-Group Trust: The Impact of Income Inequality. Southern Economic Journal 76(4), 1049-1063

Levine, R., Lin, C., Xie, W., 2018. Corporate Resilience to Banking Crises: The Roles of Trust and Trade Credit. Journal of Financial and Quantitative Analysis 53(4), 1441-1477

Mayer, R.C., Davis, J.H., Schoorman, F.D., 1995. An integrative model of organizational trust. Academy of Management Review 20(3), 709-734.

Meng, Y., Yin, C., 2019. Trust and the cost of debt financing. Journal of International Financial Markets, Institutions \& Money 59, 58-73

Moro, A., Fink, M., 2013. Loan managers' trust and credit access for SMEs. Journal of Banking \& Finance 37, 927-936

Nguyen, T., Le, N., Freeman, N., 2006. Trust and Uncertainty: A Study of Bank Lending to Private SMEs in Vietnam. Asia Pacific Business Review 12(4), 547-568

Nooteboom, B., Berger, H., Noorderhaven, N.G., 1997. Effects of trust and governance on relational risk. The Academy of Management Journal 40(2), 308-338

Petersen, M., 2009. Estimating Standard Errors in Finance Panel Data Sets: Comparing Approaches. The Review of Financial Studies, 22(1), 435-480

Putnam, Robert D.: 1993. Making democracy work. Civic traditions in modern Italy.

Princeton: Princeton University Press 1993

Roulet, C., 2018. Basel III: Effects of capital and liquidity regulations on European bank lending. Journal of Economics and Business 95, 26-64

Sangnier, M., 2013. Does trust favor macroeconomic stability? Journal of Comparative Economics 41, 653-668

Sapienza, P., Toldra-Simats, A., Zingales, L., 2013. Understanding Trust. The Economic Journal 123, 1313-1332

Shapiro, C., Stiglitz, J., 1984. Equilibrium unemployment as a worker discipline device. American Economic Review 74(3), 433-444 
Talavera, O., Xiong, L., Xiong, X., 2012. Social Capital and Access to Bank Financing: The Case of Chinese Entrepreneurs. Emerging Markets Finance and Trade 48(1), 55-69

Shleifer, A., Vishny, R., 1997. The limits of arbitrage. The Journal of Finance 52(1), 35-55

Valverde, Santiago C., Fernández, Francisco R., 2007. The Determinants of Bank Margins in European Banking, Journal of Banking and Finance, 31(7), 2043 - 2063.

Woolridge, J. M. 2002. Econometric analysis of cross-section and panel data. Cambridge, MA: MIT Press.

Zak, J.P., Knack, S., 2001. Trust and growth. The Economic Journal 111(470), 295-321 